\title{
ANALISIS FAKTOR DAN UNIVARIAT DALAM PENENTUAN POTENSI MINERALISASI CU, PB, ZN DI HALMAHERA BAGIAN BARAT, MALUKU UTARA
}

\section{FACTOR ANALYSIS AND UNIVARIATE TO DETERMINE CU, Pb, Zn MINERALIZATION POTENTIAL IN THE WESTERN PART OF HALMAHERA, NORTH MALUKU}

\author{
Reza Mochammad Faisal', Soepriadi', Mega Fatimah Rosana², Euis Titin Yuningsih ${ }^{2}$ \\ 1)Pusat Sumber Daya GeologiJl. Soekarno-Hatta No. 444, Bandung 40254 \\ 2)Program Pascasarjana, FTG-UNPAD Jl. Dipati Ukur No. 35, Bandung, 40132 \\ Email : reza_mfaisal@yahoo.com
}

\section{SARI}

Penelitian geokimia dengan menggunakan metode analisis kandungan unsur dari perconto endapan sungai aktif -80 mesh merupakan salah satu fase awal eksplorasi terutama untuk menemukan cebakan mineral logam. Halmahera bagian barat dengan tataan geologi yang kompleks dan berada dalam jalur metalogenik yang berpotensi membentuk cebakan logam, menghasilkan rona geokimia yang sangat bervariasi dan menarik. Data geokimia sedimen sungai aktif yang tertuang dalam bentuk peta sebaran unsur menyajikan informasi awal yang penting tentang indikasi mineralisasi untuk ditindaklanjuti ke tahap penelitian lebih rinci.

Penafsiran data geokimia di wilayah penelitian telah dilakukan dengan pendekatan analisis multivariat yaitu analisis faktor. Diperoleh asosiasi unsur yang berhubungan dengan unsur target $\mathrm{Cu}, \mathrm{Pb}, \mathrm{Zn}$ dengan $\mathrm{Co}, \mathrm{Fe}, \mathrm{Ag}$ dan $\mathrm{Au}$. Litologi daerah penelitian berupa batuan volkanik berkomposisi andesit dan basalt. Terdapat indikasi mineralisasi berupa sulfida pirit dan batuan terubah yang berupa silisifikasi, propilitisasi dan argilik. Di Halmahera bagian Barat diperkirakan mineralisasi logam yang terbentuk adalah bijih sulfida hidrotermal.

Kata kunci: Geokimia, multivariat, univariat, metalogenik, mineralisasi.

\begin{abstract}
Geochemical research using the analysis method of -80 mesh of active stream sediment samples is one of the early phase of exploration, especially in finding out metallic mineral deposits. Western part of Halmahera, with its complex geologic setting and served as metallogenic region, is being potential to form metallic deposits, which create some variation and interesting geochemical performances. The geochemistry of stream sediment data in the form of elements distribution map represents basic important information of mineralization indications to follow detail research.

Geochemical interpretation of the data in the study area had been carried out with the approach of multivariate analysis namely factor analysis, The result shows that element association of $\mathrm{Cu}, \mathrm{Pb}, \mathrm{Zn}$ are correlated to the target of $\mathrm{Co}, \mathrm{Fe}, \mathrm{Ag}$ and $\mathrm{Au}$. Lithology in the research area is composed of andesite and basalt. Mineralization is indicated by pyrite sulphide and alteration is by silicification, propylitic and argillic. In the western part of Halmahera it is estimated that metal mineralization type is hydrothermal sulfide ore.
\end{abstract}

Keywords: Geochemistry, metallogenic, mineralization, multivariate, univariate. 


\section{PENDAHULUAN}

Penelitian geokimia merupakan salah satu tahapan kegiatan awal eksplorasi mineral logam. Data dan informasi hasil kegiatan ini sangat diperlukan sebagai bahan pertimbangan untuk mendeliniasi zonazona anomali unsur logam mulia dan logam dasar untuk ditindaklanjuti dengan tahapan kegiatan selanjutnya.

Maksud kegiatan penelitian geokimia ini adalah untuk melakukan pengambilan conto sedimen sungai aktif, sari dulang dan batuan termineralisasi di daerah penelitian. Adapun tujuannya adalah untuk mengetahui penyebaran unsur-unsur kimia logam dari conto yang diambil dan zona-zona anomali unsur logam $\mathrm{Cu}, \mathrm{Pb}$, Zn serta daerah prospek, mineragrafi dan mineral berat sebagai data penunjang.

Secara fisiografis daerah Halmahera Bagian Barat terletak di Mandala Halmahera Barat bagian utara dan lengan selatan Halmahera. Morfologi Mandala berupa perbukitan yang tersusun atas batuan sedimen, pada batugamping berumur Neogen dan morfologi karst dan di beberapa tempat terdapat morfologi kasar yang merupakan cerminan batuan gunung api berumur Oligosen yang dikenal sebagai tempat kedudukan sebaran mineral logam dasar dan mulia di dalam batuan gunungapi berdasarkan penyebaran mineralisasi dan jenis mineralisasi terkait dengan jalur magmatik (Sunuhadi, 2012).

Di wilayah Akelamo yang merupakan tambang emas rakyat terlihat urat kuarsa masif mengandung pirit halus menerobos batuan lava andesitik Formasi Bacan. Urat kuarsa memiliki warna putih kotor hingga coklat, setempat lapuk, struktur yang dijumpai umumnya berupa vuggy. Hasil pengukuran menunjukkan arah urat utara selatan. Batuan alterasi pada umumnya adalah berupa silisifikasi, propilitisasi sebagian argillik. (Sudarya dan Faisal, 2007).

Secara administratif lokasi penelitian dan pengambilan 153 conto sedimen sungai aktif berada di wilayah 3 Kabupaten yaitu
Kabupaten Halmahera Utara, Kabupaten Halmahera Barat dan Kota Tidore Kepulauan, Provinsi Maluku Utara (Gambar 1).

\section{METODOLOGI}

Metoda penelitian yang dilakukan adalah penelitian geokimia sedimen sungai dan batuan. Analisis laboratorium yang dilakukan adalah analisis kimia dengan menggunakan metode AAS (Atomic Absorption Spectrophotometry), metode ini mampu mendeteksi secara simultan beberapa unsur yang dilarutkan dengan asam nitrat seperti $\mathrm{Cu}, \mathrm{Pb}, \mathrm{Zn}, \mathrm{Co}, \mathrm{Mn}$, $\mathrm{Ag}, \mathrm{Li}, \mathrm{K}, \mathrm{Fe}, \mathrm{Cr}$ dan $\mathrm{Au}$ terhadap 153 conto sedimen sungai (Gambar 1).

Pengolahan data dari hasil analisis laboratorium disajikan dalam bentuk sebuah peta anomali. Pada peta akan terlihat sebaran logam dasar dengan kadar yang diperoleh dari conto geokimia sedimen sungai aktif, dimana pengolahan secara statistika menggunakan metode univariat dan multivariat. Tahap pengolahan data geokimia, diperoleh informasi dalam bentuk peta sebaran unsur tunggal maupun peta hubungan antar unsur. Pengolahan dilaksanakan untuk memperoleh gambaran tentang perilaku serta sebaran unsur, ringkasan statistik berikut grafik histogramnya. Dari sini didapat nilai latar belakang, anomali, dan estimasi tentang populasi unsurnya.

Digunakan program SPSS, untuk mencari anomali unsur dan hubungan multi unsur/kekerabatan melalui analisis univariat dan multivariat yaitu analisis faktor. Analisis faktor secara statistik adalah untuk menggambarkan hubungan-hubungan kovarian antara beberapa variabel yang mendasari tetapi tidak teramati, kuantitas random yang disebut faktor (Johnson \& Wichern, 2002). Tujuan analisis faktor adalah menggunakan matriks korelasi hitungan untuk mengidentifikasi jumlah terkecil dari faktor umum, Interpretasi dari faktor umum dan estimasi faktor skor dan grafik scree plot (Subash Sharma, 1996). Secara matematis skor faktor merupakan 


\section{MAKALAH ILMIAH}

pengganti konsentrasi-ppm berdasarkan hubungan linear anggota faktor, analisis bertujuan untuk memisahkan kekerabatan unsur ke dalam sejumlah kelompok yang dapat diinterpretasikan secara lebih detail Khaleelee (1966) dalam Ghazali dkk (1986) untuk memudahkan di dalam pembacaan serta penafsiran hasil pengolahan data yang sekaligus juga untuk menentukan daerah penelitian yang akan ditindak lanjuti.

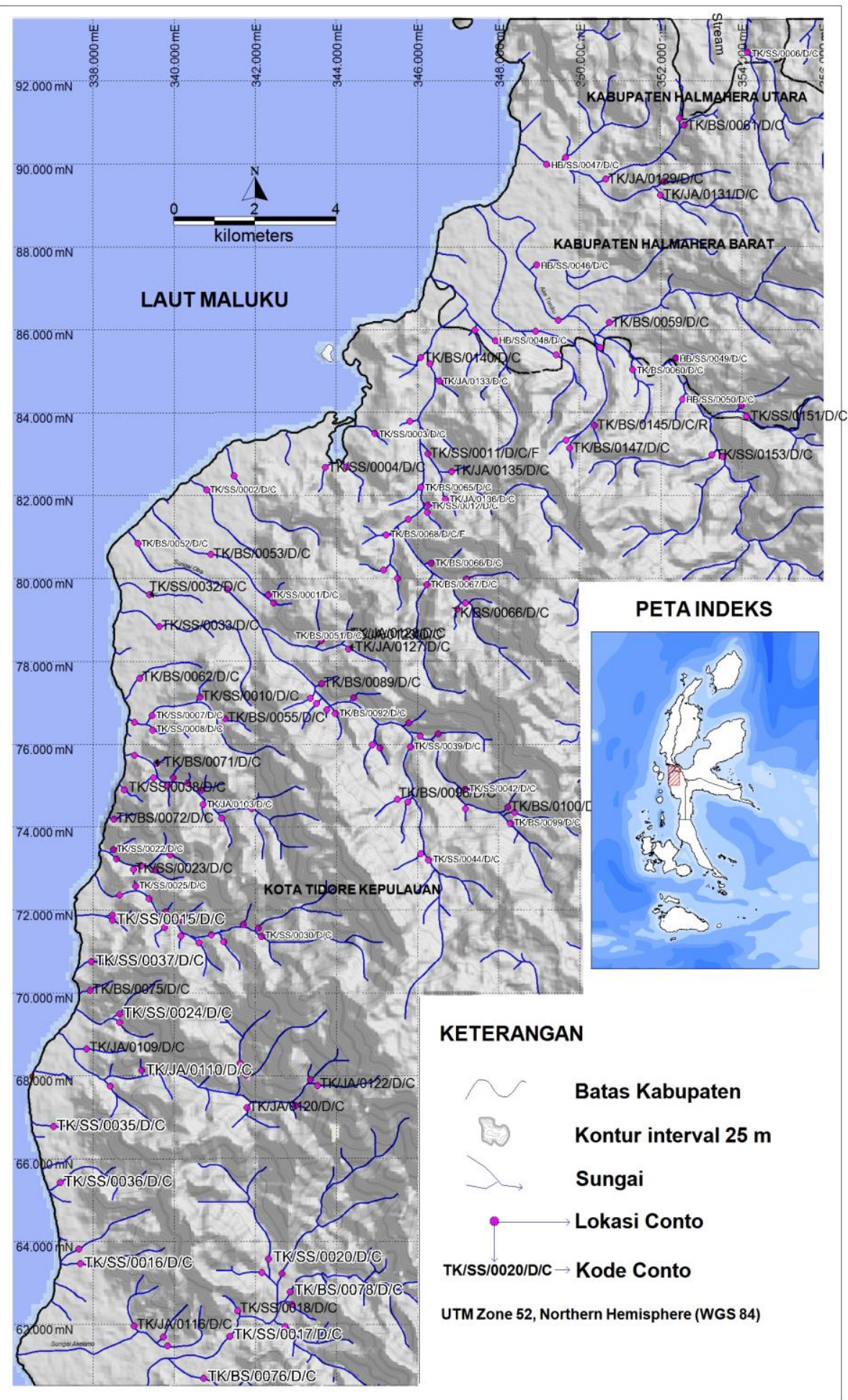

Gambar 1. Peta lokasi conto endapan sungai aktif di Halmahera Bagian Barat, Maluku Utara 


\section{GEOLOGI REGIONAL}

Menurut Apandi dan Sudana, (1980) stratigrafi regional daerah penelitian adalah sebagai berikut (Gambar 2) :

Batuan tertua di Halmahera bagian barat yaitu Formasi Bacan (Tomb) terdiri dari breksi, lava dan tuf bersusunan andesit dan basalt, setelah pengendapan sejak Eosen Akhir hingga Oligosen Awal, kegiatan gunungapi terjadi selama Oligosen Atas-Miosen Bawah. Batuan gunungapi Formasi Bacan ini tersebar luas baik di Mandala Halmahera Timur maupun di Mandala Halmahera Barat. Setelah terjadi rumpang dalam pengendapan selama Miosen Bawah bagian atas, terbentuklah cekungan luas yang berkembang sejak Miosen Atas sampai Pilosen. Pada cekungan ini diendapkan batupasir berselingan dengan napal, tufa, konglomerat dan batugamping yang membentuk Formasi Weda (Tmpw), Pengangkatan terjadi pada zaman Kuarter sebagaimana ditunjukkan oleh batugamping terumbu di pantai daerah lengan timur Halmahera.

Batuan sedimen dan Karbonat berumur Miosen-Pliosen tersebar luas di Mandala ini, kebanyakan sedimennya bersifat tufaan. Selain itu di utaranya ditemukan pula batuan gunungapi Kuarter yang masuk ke dalam Formasi Kayasa (Qpk) terdiri dari batuan gunungapi berupa lava dan breksi dan aluvium endapan pantai (Qa) terdiri dari lempung, lanau, pasir dan gravel.

Struktur lipatan berupa sinklin dan antiklin dijumpai pada Formasi Weda (Tmpw) yang berumur Miosen Tengah-Pilosen Awal. Sumbu lipatan berarah utaraselatan, timurlaut-baratdaya, dan baratlaut-tenggara. Struktur sesar terdiri dari sesar normal dan sesar naik, umumnya berarah utara-selatan dan baratlaut-tenggara.

Secara morfologi daerah penelitian memperlihatkan 3 (tiga) satuan morfologi yaitu satuan morfologi pedataran ditutupi sekitar $20 \%$ endapan pantai : lempung, lanau,kerikil dan pasir, dan \pm sekitar $80 \%$ termasuk Formasi Bacan: breksi, lava, napal tuf, konglomerat dan batugamping menempati bagian barat daerah penyelidikan memanjang utara selatan dengan ketinggian $0-75$ meter di atas permukaan laut. Satuan perbukitan bergelombang menempati bagian utara daerah penelitian dengan ketinggian 100 - 500 meter di atas permukaan laut dengan aliran sungai mengalir dari timur ke barat. Satuan ini ditutupi oleh endapan aluvium dan breksi dari Formasi Kayasa. Lava dan tuf bersusunan andesit dan basal. Satuan perbukitan tinggi, dengan ketinggian berkisar dari $500-975 \mathrm{~m}$ di atas permukaan laut. Daerah perbukitan tinggi ini ditutupi oleh batupasir, napal, tuf, konglomerat dan batugamping (Formasi Weda).

\section{HASIL DAN ANALISIS}

Kondisi geologi daerah penyelidikan yang hampir $70 \%$ ditempati oleh batuan vulkanik terdiri Formasi Bacan dan Formasi Kayasa berumur Tersier-Kuarter. Analisis petrografi dari singkapan berupa tuf pada titik TK/BS/0096 $\mathrm{R}$ di cabang kanan Sungai Oba, menunjukkan tekstur piroklastik, berbutir halus hingga berukuran 1,0 mm, bentuk butir menyudut - menyudut tanggung, disusun oleh sedikit fragmen batuan, fragmen plagioklas, biotit, mineral opak dan kuarsa di dalam masadasar gelas (Gambar 3).

Hasil petrografi lainnya berupa batuan andesit di titik TK/JA/0145 $\mathrm{R}$ di cabang kanan Sungai Ake Toniku, menunjukkan tekstur porfiritik dan glomeroporfiritik, berbutir sangat halus hingga berukuran 2,5 mm, bentuk anhedral - subhedral, disusun oleh fenokris plagioklas, piroksen, mineral opak di dalam masa disusun oleh fenokris plagioklas, piroksen, mineral opak di dalam masa dasar mikrolit plagioklas, kriptokristalin dan gelas (Gambar 4).

Hasil analisis mineragrafi conto dari lokasi TK/BS/0099/R di cabang kanan Sungai Oba, mineral logam yang teridentifikasi adalah pirit. Pirit, berwarna putih kekuningan, berbutir sangat halus 
$(<0,05 \mathrm{~mm})$ hingga halus $( \pm 0,12 \mathrm{~mm})$, bentuk anhedral, bersifat isotrop, tersebar tidak merata dalam massa batuan. Hidrous Iron Oxide, berwarna abu-abu dengan refleksi dalam dominan merah, terdapat menggantikan pirit melalui pinggir (gambar 5). Dari hasil pemeriksaan conto mineral berat menunjukkan komposisi mineral (\%) yang menonjol dan memberikan arti terhadap indikasi pembentukan mineralisasi berupa pirit.
Pirit berwarna kuning pucat, kilap metalik, bentuk butir kubik-menyudut tanggung, merupakan salah satu mineral indikator untuk pembentukan mineralisasi hydrothermal sulfides ores. Hasil pemeriksaan mineralogi butir menunjukkan adanya pirit meskipun tidak terlalu menonjol secara komposisi di lokasi TK/SS/0045/C, TK/SS/0068/C, TK/SS/00 99/C, TK/SS/0135/C, TK/SS/0143/C dan TK/SS/ 0154/C (Gambar 6).

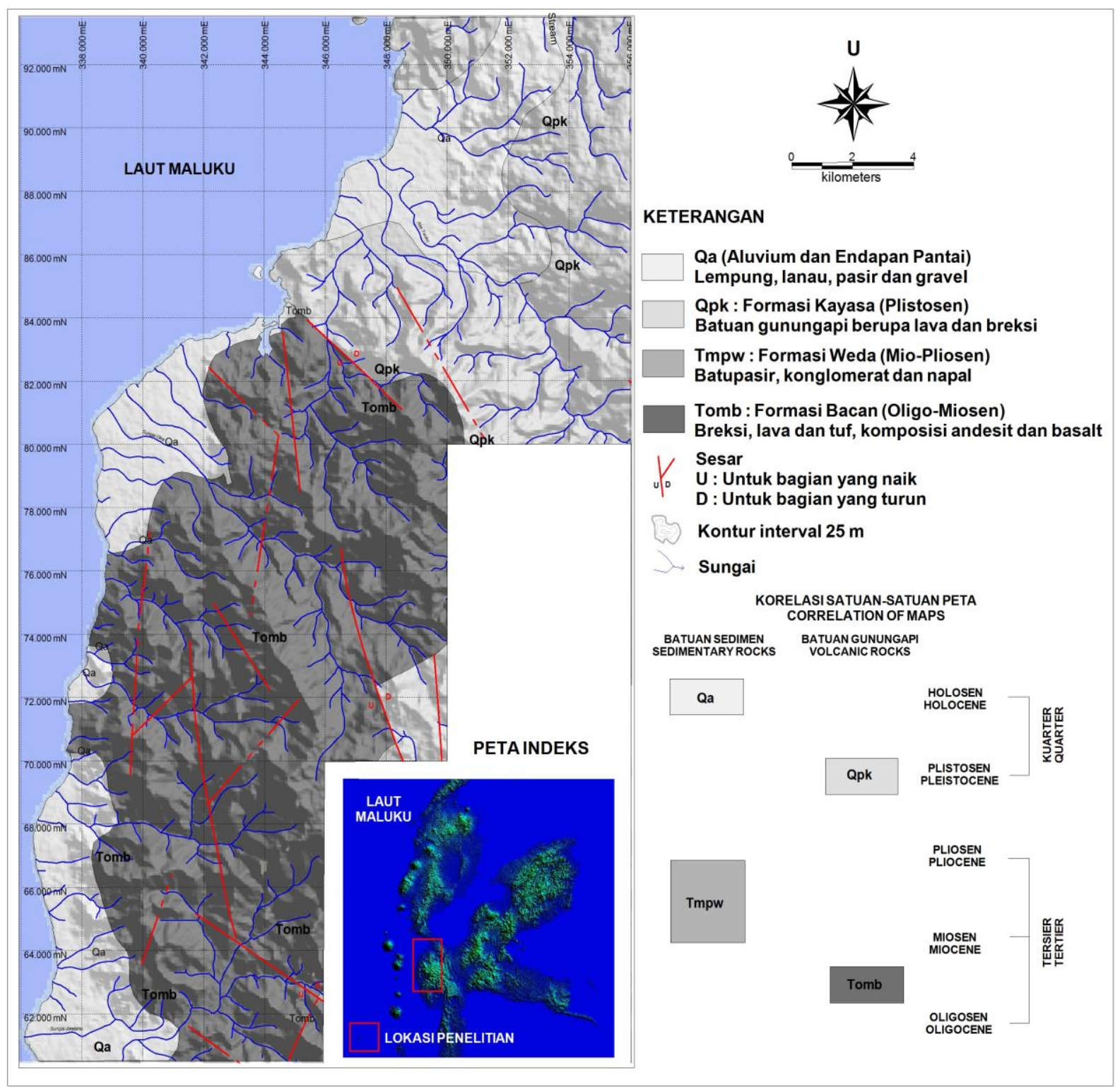

Gambar 2. Peta geologi regional Halmahera Bagian Barat, Maluku Utara (Modifikasi Apandi \& Sudana, 1980) 


\section{MAKALAH ILMIAH}
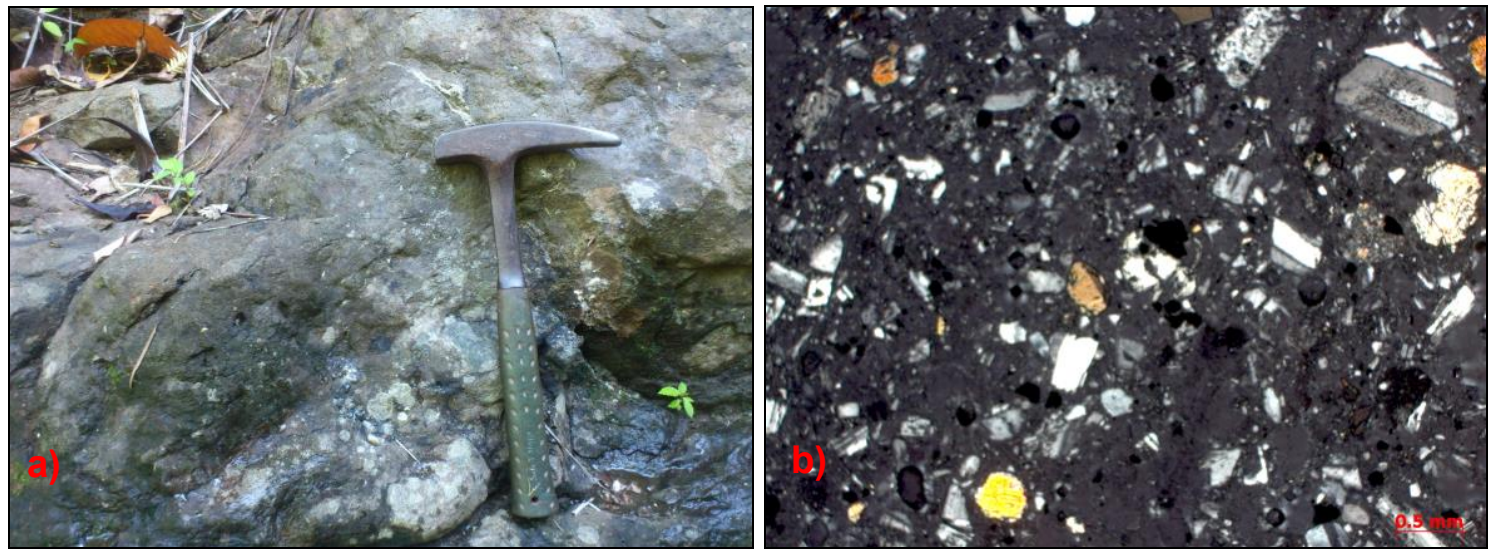

Gambar 3. a) Singkapan tuf gunungapi lokasi TK/BS/0096 R di cabang kanan Sungai Oba dan b) hasil fotomikrograf kristal vitric tuf
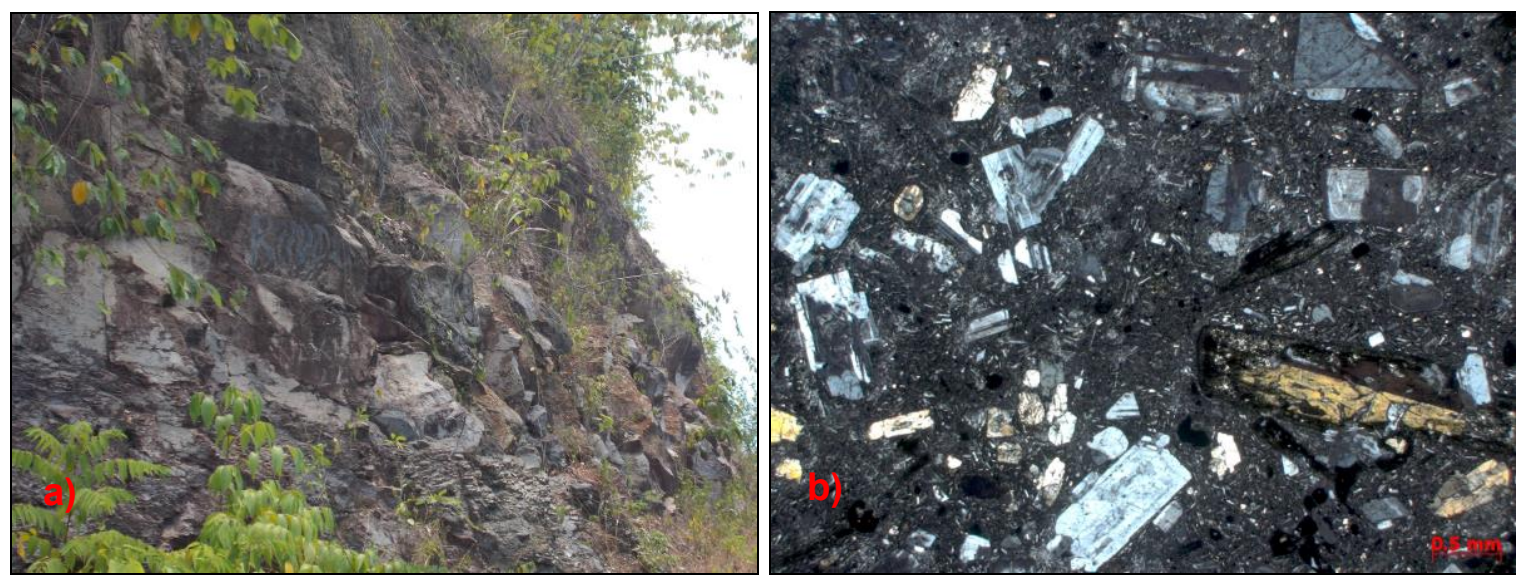

Gambar 4. a) Singkapan andesit lokasi TK/JA/0145 R di cabang kanan Sungai Ake Toniku dan b) hasil fotomikrograf andesit
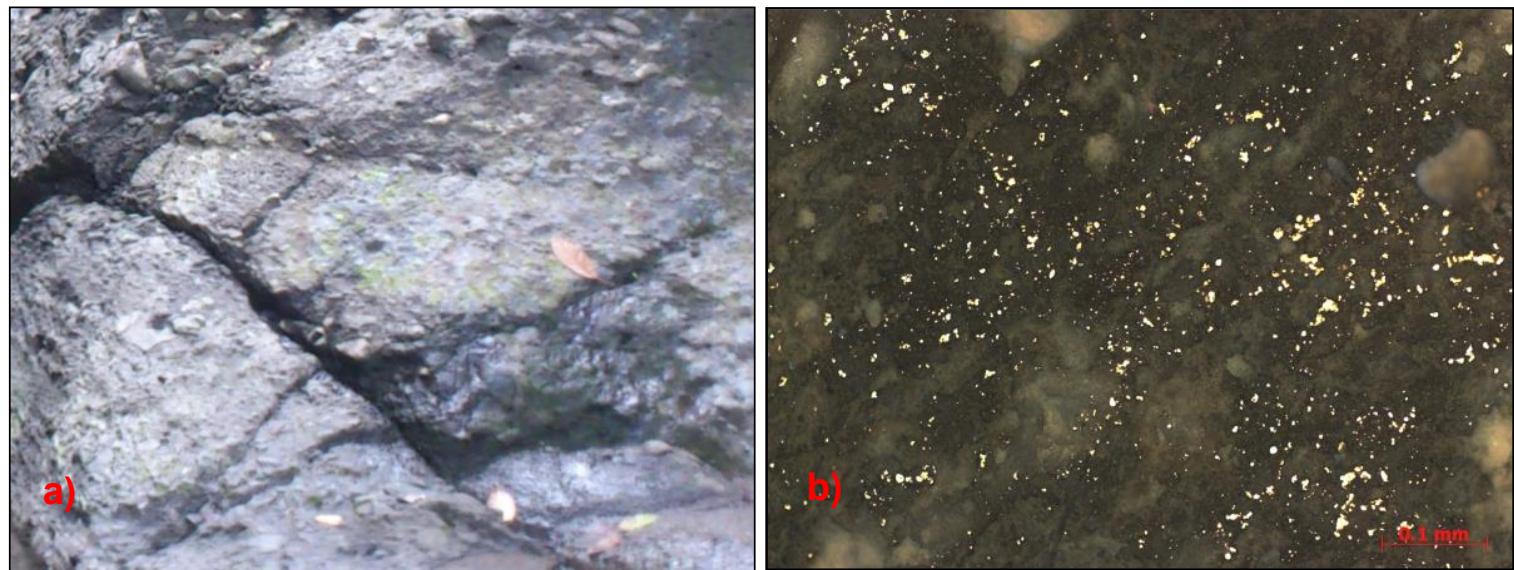

Gambar 5. a) Singkapan tuf gunungapi lokasi TK/BS/0096 R di cabang kanan Sungai Oba dan b) hasil fotomikrograf sayatan poles, pirit sangat halus 


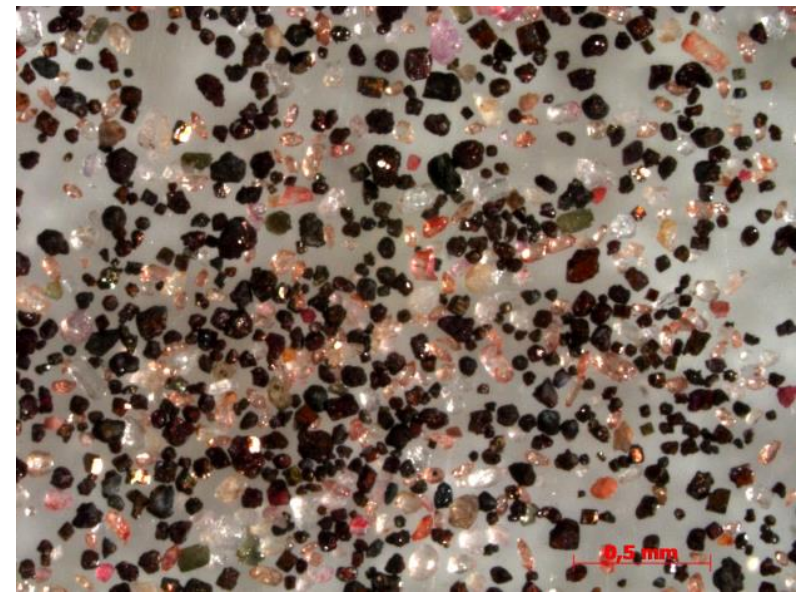

Gambar 6. Mineral berat TK/SS/0045/C mineral, Amfibol, Zirkon, Piroksen Pirit

Berdasarkan analisis statistik univariat 11 unsur logam lebih di fokuskan kepada tiga unsur yaitu $\mathrm{Cu}, \mathrm{Pb}$ dan $\mathrm{Zn}$. Ringkasan statistik geokimia endapan sungai aktif (Tabel 1). Membandingkan kesamaan ciri geokimia dan geologi tersebut, pada penelitian ini dengan cara pemodelan menggunakan sistem informasi geografis dan statistik. Penentuan kelas geokimia untuk mendapatkan daerah peninggian nilai kandungan unsur sebagai indikasi anomali menurut Rose dkk. (1979) dalam Ghazali dkk. (1986) Menghitung dengan rumus nilai rata-rata ditambah antara dua atau tiga kali nilai simpangan baku, terhadap unsur $\mathrm{Cu}, \mathrm{Pb}$ dan $\mathrm{Zn}$ sehingga diperoleh ringkasan 4 kelas interval unsur dengan rumus (tabel 2).

Tabel 1. Ringkasan statistik geokimia conto endapan sungai aktif $\mathrm{Cu}, \mathrm{Pb}$, dan $\mathrm{Zn}$

\begin{tabular}{|c|c|c|c|c|c|c|}
\hline \multirow[t]{2}{*}{ Unsur } & \multirow{2}{*}{$\begin{array}{l}\text { Rata- } \\
\text { Rata } \\
\text { (ppm) }\end{array}$} & Standard & Jumlah & \multirow{2}{*}{$\begin{array}{l}\text { Min } \\
\text { (ppm) }\end{array}$} & \multirow{2}{*}{$\begin{array}{l}\text { Maks } \\
\text { (ppm) }\end{array}$} & Rata-Rata \\
\hline & & $\begin{array}{l}\text { Deviasi } \\
\text { (ppm) }\end{array}$ & Analisis & & & $\begin{array}{l}\text { Pada Kerak Bumi } \\
\text { (ppm) }\end{array}$ \\
\hline
\end{tabular}

(Rose, 1979)

\begin{tabular}{ccccccc} 
& & & & & (Berkman, 2001). \\
\hline $\mathbf{C u}$ & 47.79 & 21.885 & 153 & 8 & 116 & 5 \\
\hline $\mathbf{P b}$ & 22.87 & 24.064 & 153 & 6 & 299 & 12 \\
\hline $\mathbf{Z n}$ & 75.76 & 26.396 & 153 & 32 & 181 & 130
\end{tabular}

Tabel 2. Ringkasan kelas interval conto endapan sungai aktif $\mathrm{Cu}, \mathrm{Pb}$, dan $\mathrm{Zn}$ Unsur Kelas Interval

\begin{tabular}{crccc} 
& \multicolumn{1}{c}{$\mathbf{1}$} & $\mathbf{2}$ & $\mathbf{3}$ & $\mathbf{4}$ \\
\hline $\mathbf{C u}(\mathbf{p p m})$ & $91.57-116$ & $80.62-91.56$ & $69.68-80.61$ & $<69.67$ \\
\hline $\mathbf{P b}(\mathbf{p p m})$ & $71-299$ & $58.97-70.99$ & $46.94-58.96$ & $<46.93$ \\
\hline $\mathrm{Zn} \mathrm{(ppm)}$ & $128.55-181$ & $115.36-128.54$ & $102.16-115.35$ & $<102.15$ \\
\hline
\end{tabular}

\section{Tembaga $(\mathrm{Cu})$}

Kandungan unsur $\mathrm{Cu}$ rata-rata 47,79 ppm, dengan kisaran 8 ppm sampai dengan 116 ppm, simpangan baku 21,88 ppm. Terdapat dua kandungan unsur $\mathrm{Cu}$ yang tinggi yaitu 115 ppm pada titik lokasi TK/BS/0081/D/C di cabang kanan Sungai Simake, Desa Oba, Kecamatan Oba Utara, dan kandungan $\mathrm{Cu} 116 \mathrm{ppm}$ pada titik lokasi TK/SS/0024/D/C di sebelah utara Desa Somahode, Kecamatan Oba Tengah. Daerah dengan konsentrasi unsur $\mathrm{Cu}$ yang tinggi dan cukup luas sebarannya adalah di daerah sebelah selatan dan baratdaya penelitian yaitu wilayah Oba Utara, Oba Tengah dan Guraping dengan sebaran kelas interval tertinggi antara 80.62 - 91.56 


\section{MAKALAH ILMIAH}

ppm dan antara 91.57 - 116 ppm, dimana anomali tertinggi berada di wilayah batuan gunungapi berumur Oligo-Miosen dan aluvium yang diperkirakan akibat adanya perpindahan unsur yang berasal dari batuan gunungapi yang masuk kedalam Formasi Bacan, serta dikontrol struktur regional berarah utara-selatan (Gambar 7).

\section{Timbal (Pb)}

Kandungan unsur $\mathrm{Pb}$ rata-rata 22,87 ppm, dengan kisaran 6 ppm sampai dengan 299 ppm, simpangan baku 24,06 ppm. Terdapat dua kandungan unsur $\mathrm{Pb}$ yang tinggi yaitu 70 ppm di Sungai Somahade sebelah timur, Desa Somahade, Kecamatan Oba Tengah, dan kandungan $\mathrm{Pb} 299$ ppm pada cabang kanan sungai Oba sebelah barat Sofifi, Kecamatan Oba Utara.

Daerah dengan konsentrasi tinggi hanya terdapat di beberapa titik dengan sebaran kelas interval tertinggi antara 58,97 - 70,99 ppm dan antara 71 - 229 ppm, dimana batuan penyusun yang berada di lokasi ini berupa batuan gunung api berumur OligoMiosen dengan komposisi andesit dan basalt termasuk ke dalam Formasi Bacan (Gambar 8).

\section{Seng (Zn)}

Kandungan unsur Zn rata-rata 75,76 ppm, dengan kisaran 32 ppm sampai dengan 181 ppm, simpangan baku 26,39 ppm. Terdapat dua kandungan unsur $\mathrm{Zn}$ yang tinggi yaitu 167 ppm di cabang kanan Sungai Oba sebelah tenggara, Kecamatan Oba Utara, dan kandungan $\mathrm{Zn} 181 \mathrm{ppm}$ pada titik di sebelah utara Sofifi, Kecamatan Oba Utara, (Gambar 9).

Berdasarkan hasil analisis sebaran unsur $\mathrm{Zn}$ yang bernilai tinggi dengan interval 128,55 - 181 ppm, tersebar di delapan (8) titik yang tersebar di sebelah utara yaitu daerah Jailolo Selatan yang didasari oleh batuan vulkanik intermediet (Formasi Kayasa) dan aluvium berumur Kuarter, yang diperkirakan mengalami dispersi unsur dari batuan gunungapi (Qpk). Sedangkan wilayah bagian selatan daerah penelitian diperoleh anomali unsur $\mathrm{Zn}$ tertinggi, dimana wilayah ini didasari oleh batuan gunungapi Tersier yang termasuk ke dalam Formasi Bacan serta dikontrol struktur regional secara umum berarah baratlaut-baratdaya dan timurlauttenggara.

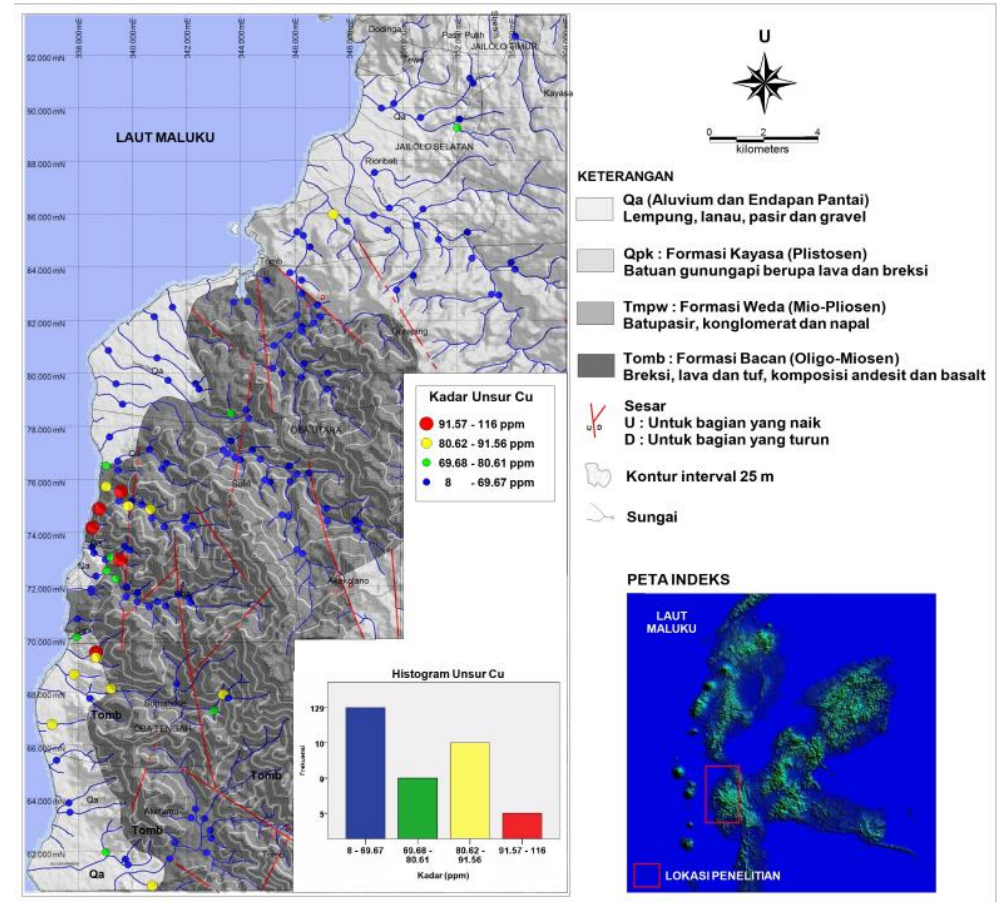

Gambar 7. Peta geologi dan sebaran unsur tembaga $(\mathrm{Cu})$ dalam conto endapan sungai aktif di Halmahera Bagian Barat, Maluku Utara 


\section{MAKALAH ILMIAH}

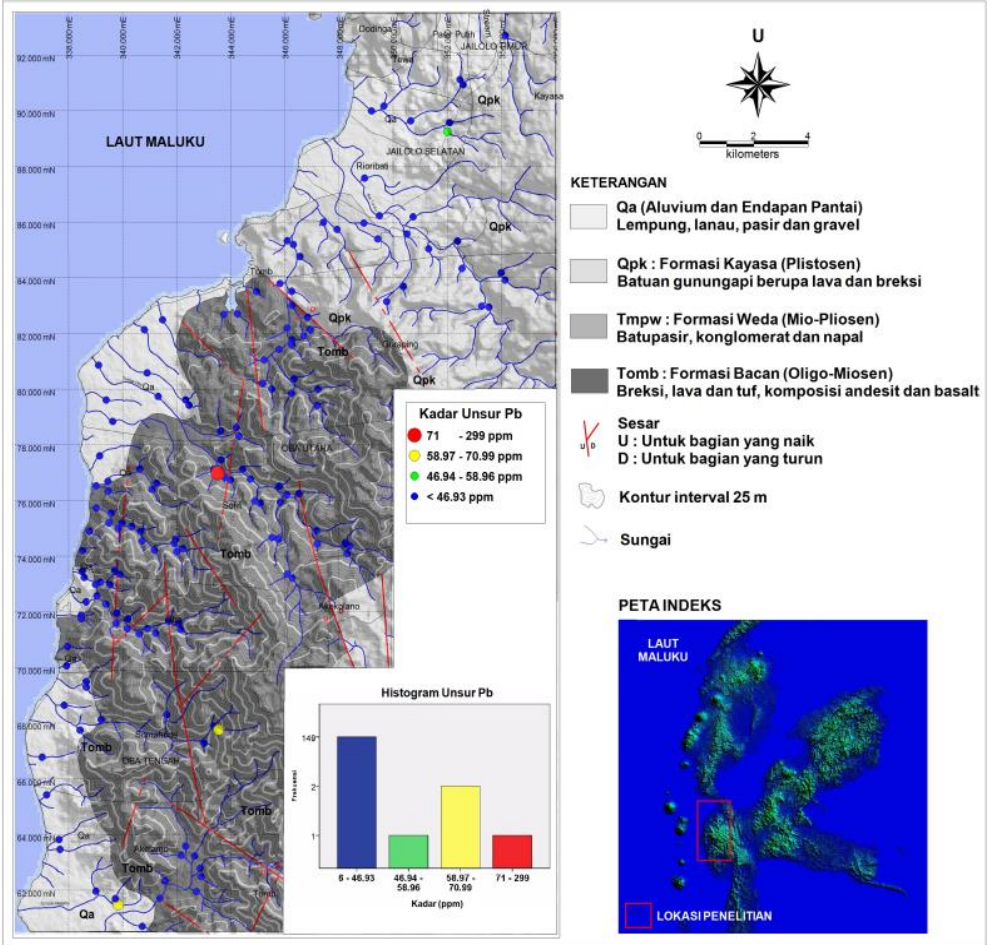

Gambar 8. Peta geologi dan sebaran unsur timbal $(\mathrm{Pb})$ dalam conto endapan sungai aktif di Halmahera Bagian Barat, Maluku Utara

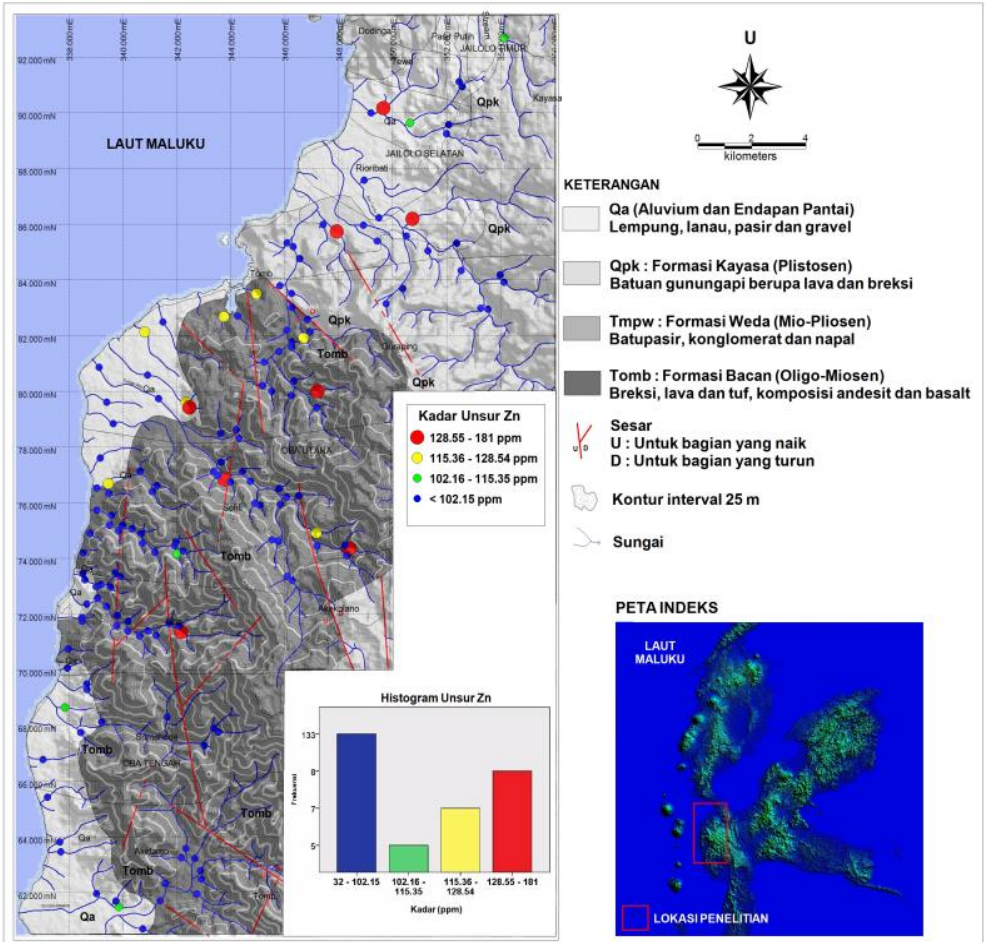

Gambar 9. Peta geologi dan sebaran unsur seng ( $\mathrm{Zn})$ dalam conto endapan sungai aktif di Halmahera Bagian Barat, Maluku Utara

Pengolahan statistik multivariat untuk menentukan adanya asosiasi unsur di daerah penelitian menggunakan analisis korelasi dan analisis faktor. Berdasarkan sedimen sungai aktif sebanyak 153 sampel dianalis kandungan kimia sebanyak 11 jenis unsur yaitu $\mathrm{Cu}, \mathrm{Pb}$, $\mathrm{Zn}, \mathrm{Co}, \mathrm{Mn}, \mathrm{Ag}, \mathrm{Li}, \mathrm{K}, \mathrm{Fe}, \mathrm{Cr}$ dan Au. 


\section{MAKALAH ILMIAH}

Dalam menentukan analisis faktor dapat dilihat dari jumlah faktor yang akan ditampilkan sebagai faktor pengganti perlu ditelaah "eigenvalues" yang dapat diartikan sebagai bobot nilai. Penentuan faktor pengganti diambil dari nilai eigenvalues yang bernilai $\geq 1$ atau dapat dilihat dari plot scree test (Gambar 10).

Faktor pengganti diperlihatkan oleh garis penghubung berlereng curam pada batasan eigenvalues $\geq 1$, selanjutnya untuk mengetahui variabel-variabel yang menjadi anggota dari faktor pengganti tersebut dengan cara menganalis koefisien korelasi faktor (Tabel 3) yaitu nilai-nilai koefisien faktor antara variabelvariabel dengan faktor pengganti, karena pada umumnya komponen korelasi yaitu faktor pengganti dan unsur $\leq 30$ maka batasan nilai signifikan menjadi tinggi, dalam hal ini ditetapkan $\geq 0.5$. Dari hasil analisis statistik yang terintegrasi dengan peta kekerabatan unsur, diperoleh pengelompokan sebagai berikut :
a. Faktor 1 : Cu-Co-Ag-Li-K-Cr
b. Faktor 2 : Zn-Co-Mn-Fe-Au
c. Faktor 3 : Pb-Ag

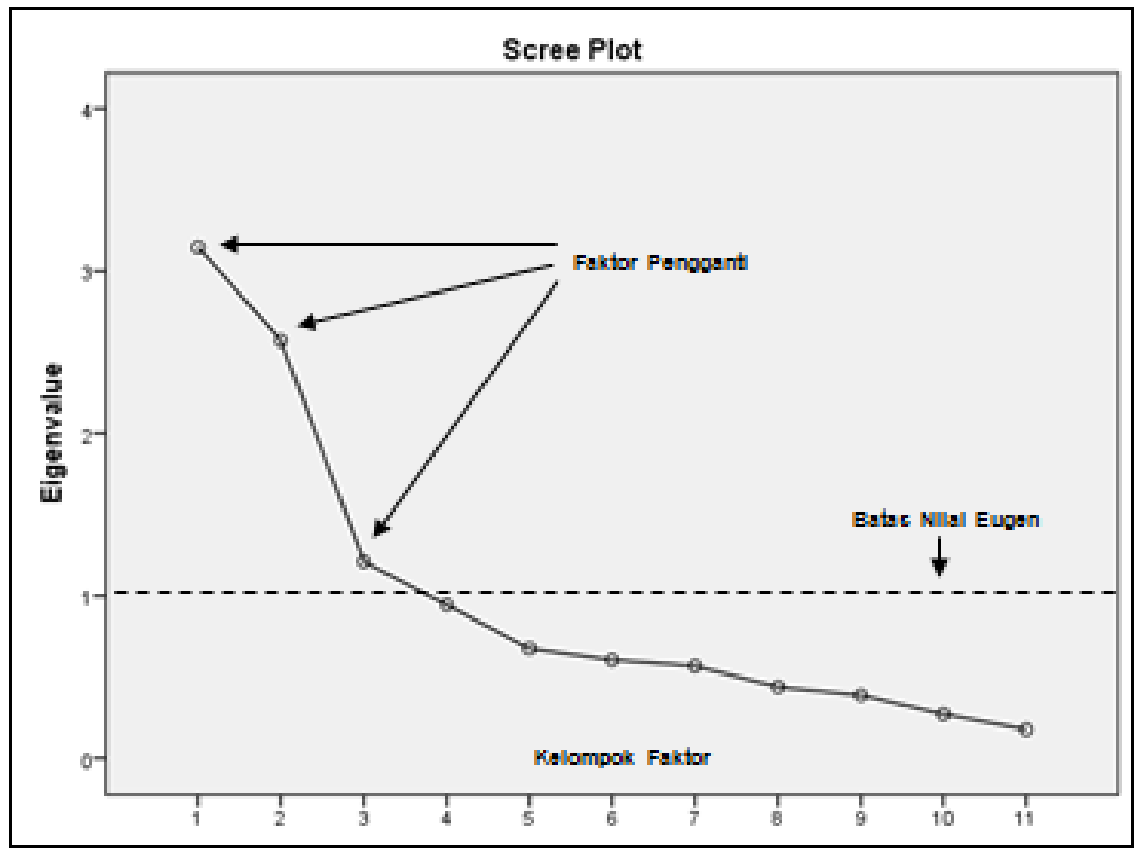

Gambar 10. Grafik scree plot test

Tabel 3. Skor faktor dari 3 faktor pengganti

\begin{tabular}{crrr}
\hline Unsur & $\begin{array}{c}\text { Faktor } \\
\mathbf{1}\end{array}$ & $\begin{array}{c}\text { Faktor } \\
\mathbf{2}\end{array}$ & $\begin{array}{c}\text { Faktor } \\
\mathbf{3}\end{array}$ \\
\hline $\mathbf{C u}$ & $\mathbf{0 . 8 1 1}$ & -0.011 & 0.112 \\
\hline $\mathbf{P b}$ & -0.035 & 0.041 & $\mathbf{0 . 7 8 2}$ \\
\hline $\mathbf{Z n}$ & -0.169 & $\mathbf{0 . 8 2 3}$ & 0.14 \\
\hline $\mathbf{C o}$ & $\mathbf{0 . 5}$ & $\mathbf{0 . 7 5 2}$ & 0.019 \\
\hline $\mathbf{M n}$ & -0.045 & $\mathbf{0 . 6 1 4}$ & 0.359 \\
\hline $\mathbf{A g}$ & $\mathbf{0 . 6 2 4}$ & 0.161 & $\mathbf{0 . 5 0 5}$ \\
\hline $\mathbf{L i}$ & $\mathbf{0 . 8 0 7}$ & -0.152 & -0.17 \\
\hline $\mathbf{K}$ & $\mathbf{0 . 7 7 1}$ & -0.095 & 0.013 \\
\hline $\mathbf{F e}$ & 0.104 & $\mathbf{0 . 8 4 6}$ & -0.033 \\
\hline $\mathbf{C r}$ & $\mathbf{0 . 5 3 8}$ & 0.346 & -0.369 \\
\hline $\mathbf{A u}$ & -0.196 & $\mathbf{0 . 5 1 1}$ & -0.221 \\
\hline
\end{tabular}


Hasil analisis dari penggabungan unsur tunggal (univariate) berupa pola sebaran anomali unsur $\mathrm{Cu}, \mathrm{Pb}, \mathrm{Zn}$ dan unsur jamak (multivariate) terhadap unsur lainnya yaitu $\mathrm{Co}, \mathrm{Mn}, \mathrm{Ag}, \mathrm{Li}, \mathrm{K}, \mathrm{Fe}, \mathrm{Cr}$ dan $\mathrm{Au}$ sebagai penguat data untuk melihat pengelompokan unsur. Pengelompokan ini dipetakan dalam bentuk sebaran interpolasi dan kelompok faktor yang terdiri dari skor faktor diperoleh asosiasi :

Faktor 1 : Cu-Co-Ag-Li-K-Cr, wilayah peninggian faktor 1 , pola sebaran peninggian anomali umumnya berada di bagian tengah barat ke selatan wilayah penelitian Kota Tidore Kepulauan, kemungkinan asosiasi antar unsur $\mathrm{Cu}-\mathrm{Ag}$ tersebut berhubungan dengan jenis batuan gunungapi berumur Tersier hingga Kuarter diperoleh 7 daerah potensi mineralisasi Cu (Gambar 11).

Faktor 2 : Zn-Co-Mn-Fe-Au, wilayah peninggian faktor 2, pola sebaran multi unsur terkuat berada di bagian utara tepatnya di Kabupaten Halmahera Barat yang dikontrol litologi batuan gunungapi berumur Kuarter, dan sebagian tersebar di bagian tengah barat wilayah penelitian yang termasuk ke dalam wilayah Kota Tidore Kepulauan. Peninggian tersebut diperkirakan berkaitan dengan mineralisasi sulfida, yaitu dengan dijumpainya urat kuarsa mengandung logam mulia dan logam dasar, serta berdasarkan hasil analisis mineragrafi pada batuan tuf TK/BS/099R ditemukan sulfida pirit dan berdekatan dengan batuan terubah berupa silifikasi, propilitisasi dan argilik. Di bagian utara daerah penelitian, diperoleh delapan daerah potensi mineralisasi $\mathrm{Zn}$ (Gambar 12).

Faktor 3 : $\mathrm{Pb}-\mathrm{Ag}$, wilayah peninggian faktor 3, pola sebaran peninggian $\mathrm{Pb}-\mathrm{Ag}$ berada di bagian tengah barat ke arah selatan wilayah penelitian yang masuk ke dalam Kota Tidore Kepulauan, dimana pola sebaran peninggian cenderung mengikuti pola struktur geologi, sebagai indikasi adanya kontrol litologi batuan gunungapi berumur Tersier-Kuarter, diperoleh 3 potensi mineralisasi $\mathrm{Pb}$ (Gambar 13). 


\section{MAKALAH ILMIAH}

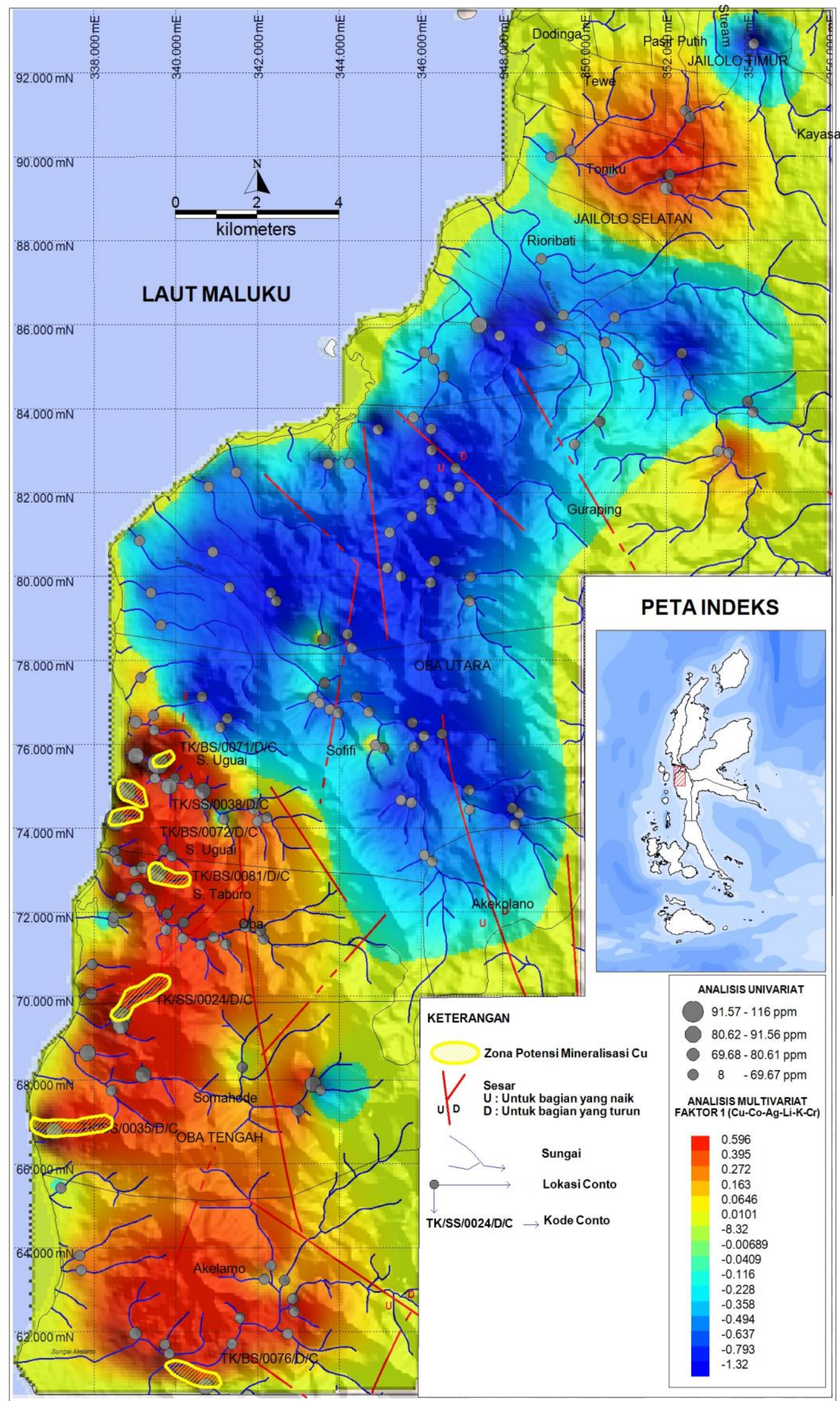

Gambar 11. Peta sebaran unsur $\mathrm{Cu}$, Faktor 1 (Cu-Co-Ag-Li-K-Cr), dan potensi mineralisasi $\mathrm{Cu}$, Daerah Halmahera Bagian Barat, Maluku Utara 


\section{MAKALAH ILMIAH}

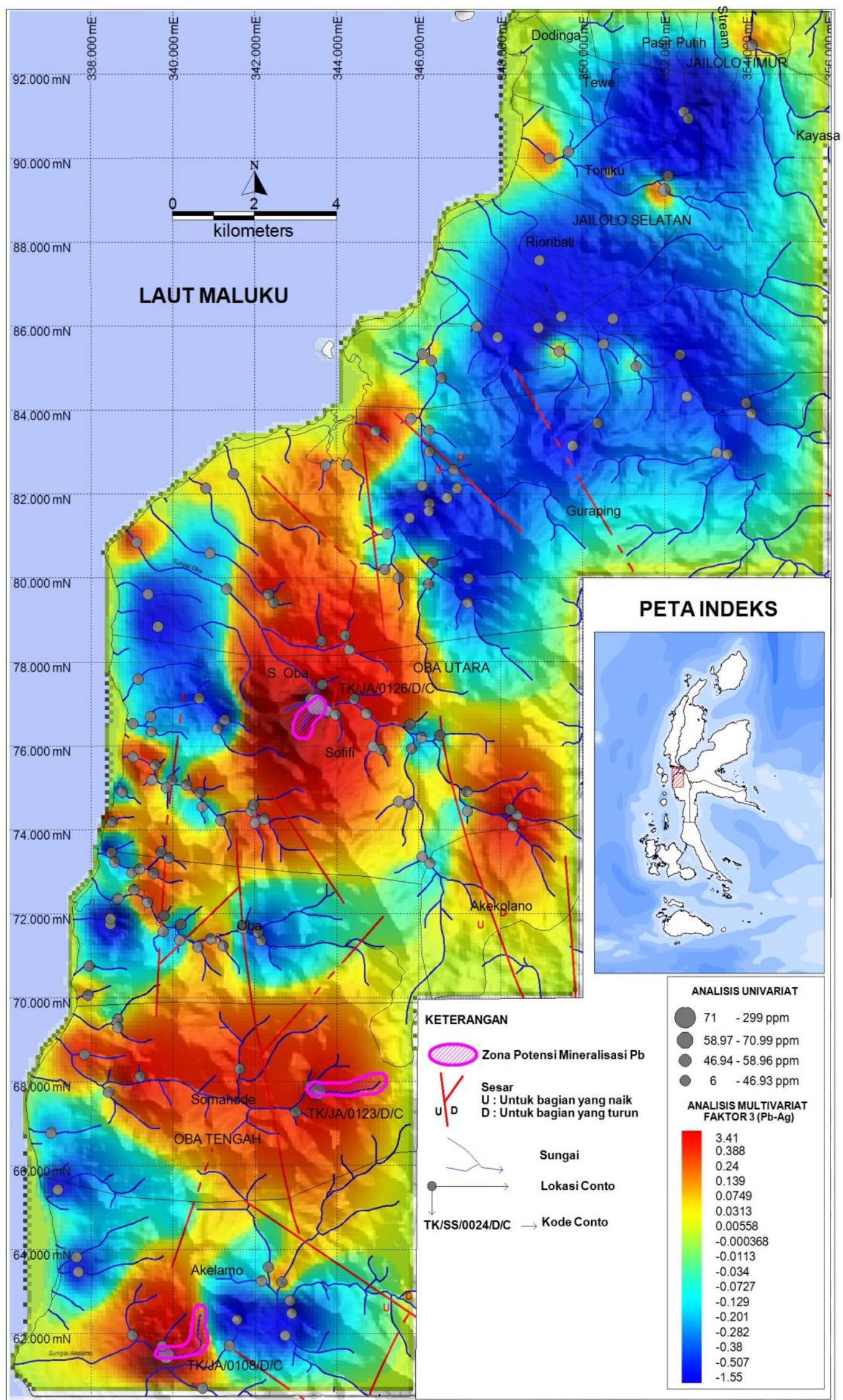

Gambar 12. Peta sebaran unsur $\mathrm{Pb}$, Faktor $3(\mathrm{~Pb}-\mathrm{Ag})$, dan potensi mineralisasi $\mathrm{Pb}$, Daerah Halmahera Bagian Barat, Maluku Utara 


\section{MAKALAH ILMIAH}

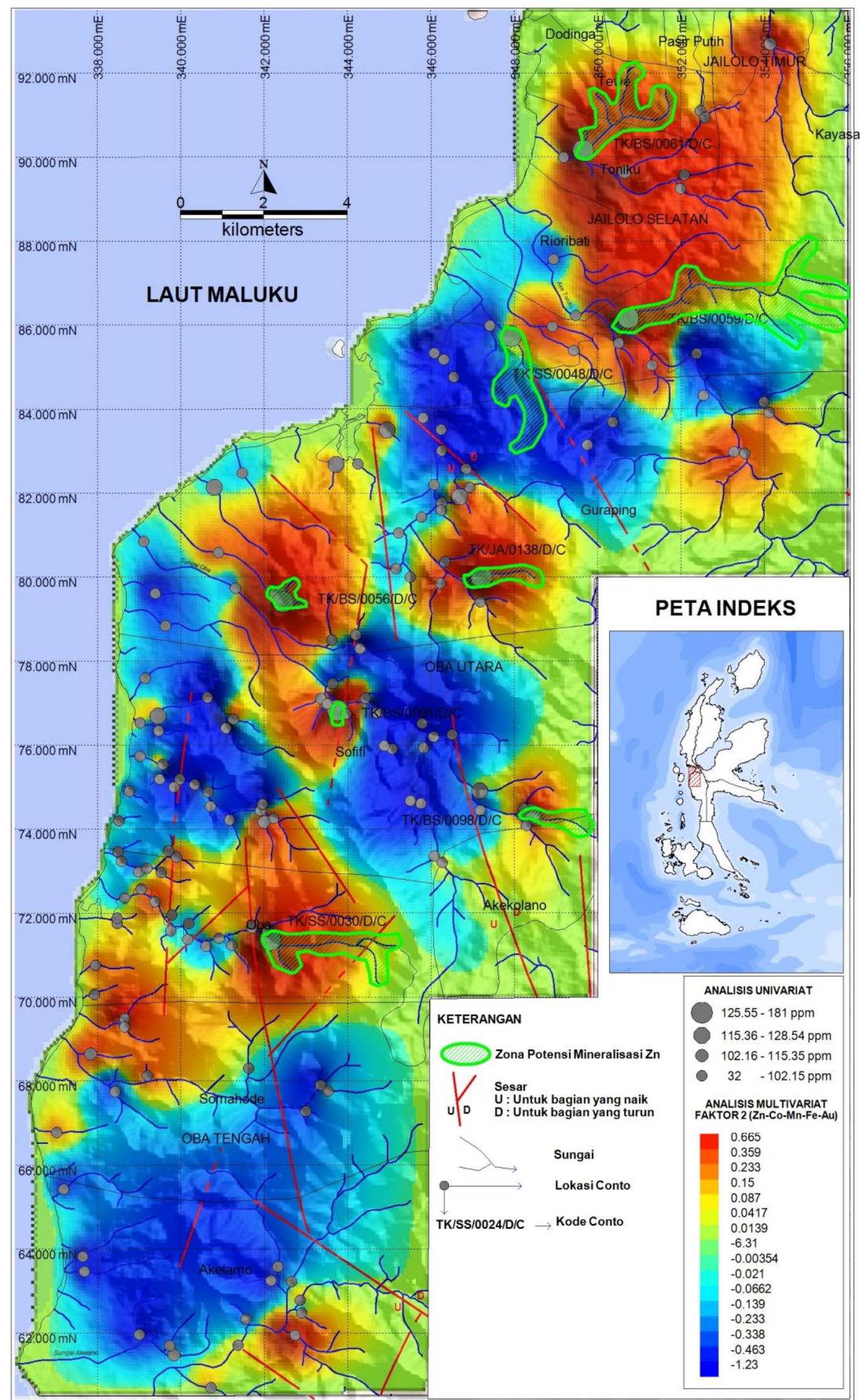

Gambar 13. Peta sebaran unsur Zn, Faktor 2 (Zn-Co-Mn-Fe-Au), dan potensi mineralisasi Zn, Daerah Halmahera Bagian Barat, Maluku Utara 


\section{HASIL DAN PEMBAHASAN}

Daerah penelitian termasuk ke dalam Mandala Halmahera Barat yang merupakan jalur mineralisasi logam dasar berumur Oligosen-Miosen. Batuan penyusun didominasi oleh batuan gunungapi terdiri dari breksi, lava dan Tufa yang bersifat andesitik dan basal berumur Tersier dan Kuarter, dengan struktur lipatan berupa sinklin dan antiklin berarah utara-selatan, timurlautbaratdaya, dan baratlaut-tenggara.

Potensi mineralisasi $\mathrm{Cu}$ di wilayah penelitian berdasarkan penggabungan data anomali unsur tunggal yang digabungkan dengan analisis multivariat faktor 1 (Cu-Co-Ag-Li-K-Cr) diperoleh ikatan unsur $\mathrm{Cu}$ dengan $\mathrm{Ag}$ diperkirakan berhubungan dengan litologi batuan batuan gunungapi berumur Tersier yang masuk kedalam Formasi Bacan. Diperoleh daerah potensi mineralisai berada pada catchmen area sebanyak 7 lokasi yaitu 4 lokasi berdekatan dengan lokasi TK/SS/0023/D/C di Cabang Sungai Simake, TK/SS/0038/D/C dan lokasi TK/BS/0071/D/C di Sungai Uguay dan lokasi TK/BS/0072/D/C di Sungai Tuguwae yang masuk ke dalam wilayah Kecamatan Oba Utara, 3 lokasi TK/SS/0024/D/C wilayah Somahade, TK/SS/0035/D/C wilayah Kecamatan Oba dan TK/BS/0076/D/C di Sungai Ragi yang berada pada aluvium dan endapan pantai ditafsirkan akibat kontaminasi dari sekitar lokasi pengambilan conto.

Potensi mineralisasi unsur $\mathrm{Pb}$ di wilayah penelitian berdasarkan penggabungan data anomali unsur tunggal atau univariat yang digabungkan dengan analisis multivariat diperoleh ikatan faktor $3: \mathrm{Pb}$ Ag diperoleh ikatan unsur $\mathrm{Pb}$ dengan $\mathrm{Ag}$ yang diindikasikan ada ikatan unsur yang berhubungan dengan litologi batuan batuan gunungapi berumur Tersier yang masuk kedalam Formasi Bacan diperoleh catchmen area sebanyak 3 lokasi. Titik TK/JA/0126/D/C di cabang di kanan Sungai Oba dengan anomali tertinggi 229 ppm dikontrol oleh struktur berarah utaraselatan daerah Sofifi Kecamatan Oba
Utara, lokasi titik lokasi kedua yaitu di TK/JA/0123/D/C dengan nilai anomali 70 ppm, titik lokasi ketiga yaitu di TK/JA/0108/D/C berada wilayah Kecamatan Oba Tengah penelitian dengan nilai konsentrasi unsur yaitu 62 ppm ditafsirkan dipengaruhi oleh kontaminasi endapan pantai di sekitar lokasi pengambilan conto karena berada di wilayah aluvium.

Potensi mineralisasi unsur $\mathrm{Zn}$ di daerah penelitian berdasarkan penggabungan data anomali unsur tunggal atau univariat yang digabungkan dengan analisis multivariat diperoleh ikatan faktor 2 ( $Z n$ $\mathrm{Co}-\mathrm{Mn}-\mathrm{Fe}-\mathrm{Au}$ ) diperoleh ikatan unsur $\mathrm{Zn}$ dengan $\mathrm{Fe}$, Co dan $\mathrm{Au}$ yang diperkirakan berhubungan dengan litologi batuan batuan gunungapi berumur TersierKuarter yang masuk ke dalam Formasi Bacan dan Formasi Kayasa diperoleh catchmen area sebanyak 8 lokasi. Empat lokasi catchment area berada di wilayah Formasi Bacan yaitu lokasi TK/BS/0091/D/C dengan nilai anomali unsur $\mathrm{Zn}$ tertinggi $181 \mathrm{ppm}$ TK/BS/0098/D/C di cabang kanan Sungai Oba dengan nilai 167 ppm berdekatan dengan conto mineragrafi TK/BS/0099/D/C ditemukan mineralisasi sulfida pirit pada batuan andesit tersilifikasi, lokasi TK/SS/0030/D/C yang dikontrol oleh struktur berarah utaraselatan dan TK/JA/0138/D/C termasuk ke dalam wilayah Kecamatan Oba Utara. Lokasi HB/SS/0048/D/C yang masuk kedalam Formasi Kayasa berumur Kuarter dengan nilai anomali 153 ppm termasuk ke dalam wilayah Kecamatan Jailolo Selatan. Sedangkan dua lokasi berikutnya yaitu TK/BS/0059/D/C dan TK/BS/0061/D/C berada di bagian utara wilayah Kecamatan Jailolo Selatan dan $\mathrm{HB} / \mathrm{SS} / 0048 / \mathrm{D} / \mathrm{C}$ wilayah Oba Kecamatan Oba Utara dengan batuan penyusun aluvium dan endapan pantai ditafsirkan dipengaruhi oleh kontaminasi dari sekitar lokasi pengambilan conto.

Berdasarkan hasil analisis geokimia batuan tuf termineralisasi berupa urat kuarsa pada titik TK/SS/0026/R dengan koordinat $339759.31 \mathrm{mE}, 71582.26 \mathrm{mN}$ di 


\section{MAKALAH ILMIAH}

cabang kanan Sungai Taburo diperoleh unsur Cu 1920 ppm, sedangkan unsur lainnya $\mathrm{Pb} 6$ ppm, dan Zn 64 ppm (Gambar 14). Indikasi mineralisasi untuk pembentukan logam $\mathrm{Cu}, \mathrm{Pb}$ dan $\mathrm{Zn}$ berdasarkan penggabungan hasil analisis data geokimia yang tercerminkan dari asosiasi unsur di lingkungan permukaan diperlihatkan dengan hubungan kuat antara $\mathrm{Cu}, \mathrm{Pb}, \mathrm{Zn}$ serta asosiasi $\mathrm{Co}, \mathrm{Fe}$, $\mathrm{Ag}$ dan $\mathrm{Au}$ yang dihubungkan dengan kondisi geologi regional daerah penelitian yaitu gunungapi berupa breksi, tuf dan lava dengan komposisi andesit dan basalt yang diperkuat oleh hasil petrografi.

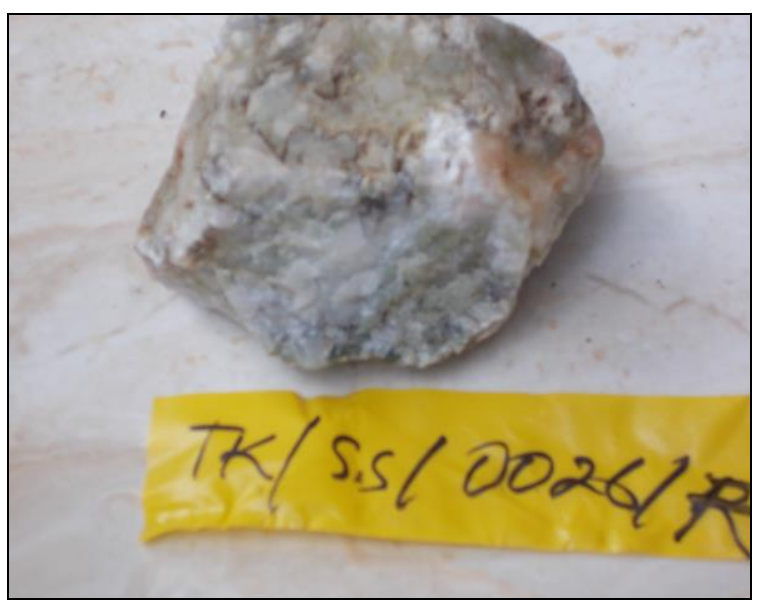

Gambar 14. Batuan tuf termineralisasi Pirit TK/SS/0026/R

\section{KESIMPULAN DAN SARAN}

Analisis anomali geokimia dan pola sebaran anomali unsur $\mathrm{Cu}, \mathrm{Pb}$ dan $\mathrm{Zn}$ yang dihubungkan dengan kekerabatan atau hubungan antar unsur dari $\mathrm{Cu}, \mathrm{Pb}$, $\mathrm{Zn}, \mathrm{Co}, \mathrm{Mn}, \mathrm{Ag}, \mathrm{Li}, \mathrm{K}, \mathrm{Fe}, \mathrm{Cr}$ dan $\mathrm{Au}$ diperoleh tiga kelompok unsur yaitu ikatan unsur Cu-Co-Ag-Li-K-Cr, Zn-Co-Mn-Fe$\mathrm{Au}$, dan $\mathrm{Pb}-\mathrm{Ag}$, akan tetapi tidak semua asosiasi unsur bisa dihubungkan dengan litologi yang berkembang di wilayah penelitian berupa gunungapi berumur Tersier-Kuarter sehingga diperoleh asosiasi $\mathrm{Cu}-\mathrm{Ag}, \mathrm{Pb}-\mathrm{Ag}$ dan $\mathrm{Zn}-\mathrm{Fe}-\mathrm{Co}-\mathrm{Au}$. Dari integrasi data diperoleh indikasi potensi mineralisasi di 11 lokasi, yaitu :

1. Potensi Cu $(80,62-116$ ppm), diperoleh 4 daerah potensi yaitu Somahade, Simake, Uguay, Tuguwae.

2. Potensi Pb (58.97-299ppm), diperoleh 2 daerah potensi yaitu Sofifi dan Somahade.

3. Potensi Cu (115,36-181 ppm), diperoleh 5 daerah potensi yaitu Sofifi, Taburo, Mungarepe, Oba dan Kayasa.

\section{UCAPAN TERIMA KASIH}

Pada kesempatan ini penulis mengucapkan terima kasih kepada anggota tim lapangan, teknisi, dan penganalisis laboratorium yang membantu kelancaran kerja hingga selesai.

\section{DAFTAR PUSTAKA}

Apandi, T. \& Sudana, D., 1980. Peta Geologi Lembar Ternate, Maluku Utara, : Pusat Survei Geologi, Bandung.

Berkman, D.A., 2001. Field Geologist' Manual. Victoria: The Australian Institute of Mining and Metallurgy

Ghazali, S.A, Muchjidin, Hariwidjaja, 1986. Penyelidikan Geokimia Endapan Sungai, Metoda dan Teknik, Direktorat Sumberdaya Mineral, Bandung.

Johnson, N. And Wichern, D., 1998. Applied Multivariate Statistical Analysis, Prentice-Hall, Englewood Cliffs, N.J. 


\section{MAKALAH ILMIAH}

Levinson, A.A., 1974, Introduction to Exploration Geochemistry, Applied Publishing Ltd., Alberta Canada.

Rose, A.W., Hawkes, H.E. \& Webb. J.S., 1979, Geochemistry in Mineral Exploration, Academic Press, London.

Sharma, S., 1996. Applied Multivariate Techniques, New-York: John Wiley \& Sons, Inc.

Sudarya,S \& Faisal, R., 2007. Inventarisasi Mineral Logam Di Kabupaten Halmahera Selatan dan Kota Tidore Kepulauan, Provinsi
Maluku Utara. Pusat Sumber Daya Geologi, Bandung.

Sunuhadi, D.N., 2012. Tahapan Eksplorasi Mineral Logam (SNI). Panduan Praktis Penyelidikan Mineral. Bab 9. 171-178. Pusat Sumber Daya Geologi, Bandung.

Soepriadi, Sulaeman, Junaedi, J., Budiharyanto K., Nurdin, A., Sukardi, 2015. Survei Geokimia Regional Bersistem Lembar Ternate A Di Pulau Halmahera, Provinsi maluku utara. Pusat Sumber Daya Geologi, Bandung.

$$
\begin{array}{ll}
\text { Diterima } & : 15 \text { September } 2015 \\
\text { Direvisi } & : 12 \text { Oktober } 2015 \\
\text { Disetujui } & : 12 \text { November } 2015
\end{array}
$$

